\title{
Connection
}

\section{Arianna Pace}

E-mail: ariannapace17@gmail.com

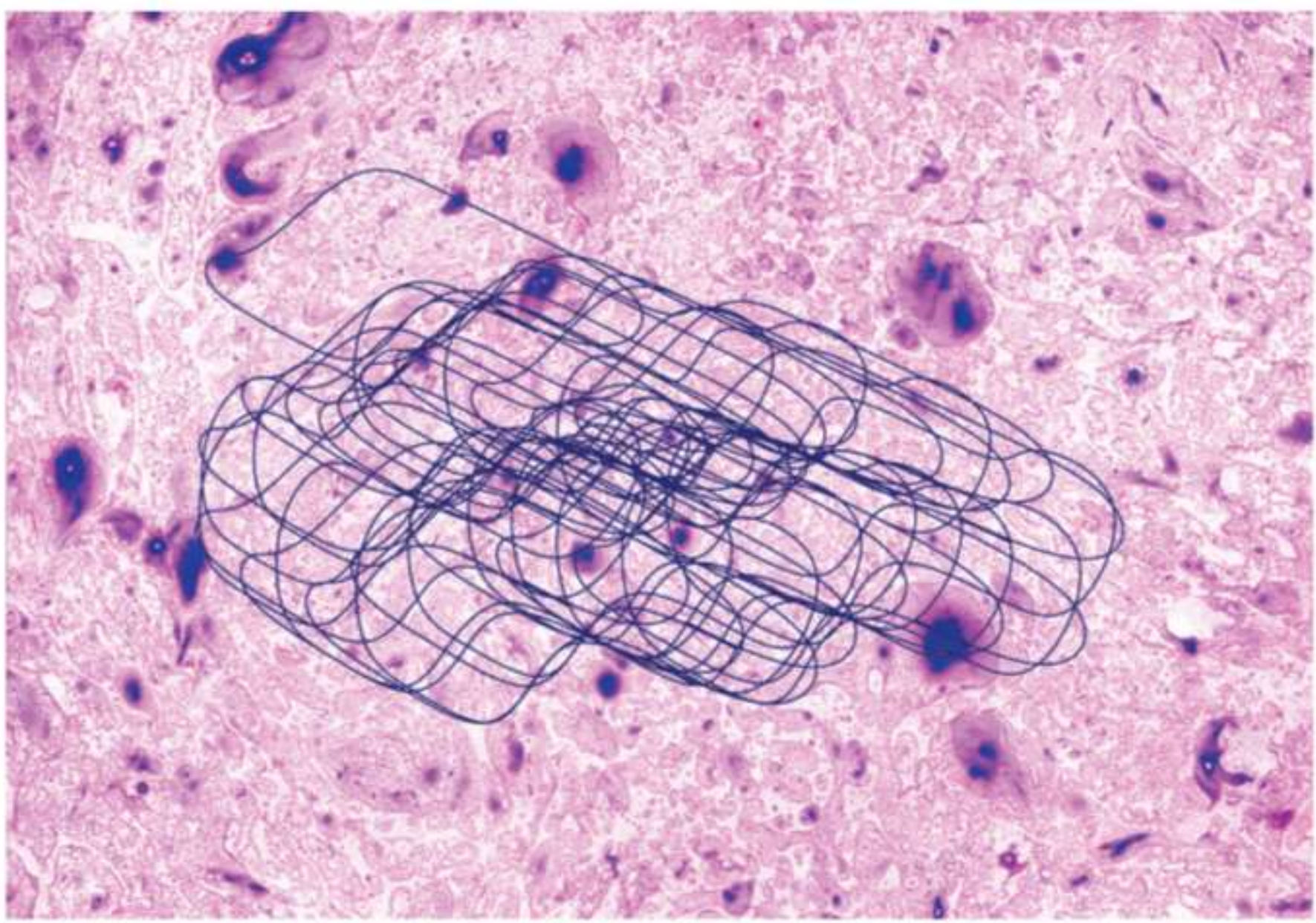

